\title{
FOREST REGENERATION QUALITY - FACTORS AFFECTING FIRST YEAR SURVIVAL OF PLANTED TREES
}

\author{
Karlis Dumins ${ }^{1,2}$, Dagnija Lazdina ${ }^{2}$ \\ ${ }^{1}$ Latvia University of Life Sciences and Technologies, Latvia \\ ${ }^{2}$ Latvian State Forest Research Institute ‘Silava’, Latvia \\ karlis.dumins@silava.lv
}

\begin{abstract}
The early stage of forestry is crucial for successful and sustainable forest management. One third of the reforested forest in Latvia is regenerated by planting with different kinds of tree seedlings. The success of forest regeneration by planting depends on correctly prepared soil and choice of the right seedling material. The aim of this study was to evaluate the impact of different soil preparation methods and used type of seedlings on tree survival and growth rate after the first growing season. For this study six young stand sites located in the north-west and central part of Latvia were established in three forest types and in each site soil was prepared in furrows by disc trenching, in mound and left untreated. Reforestation was conducted in the spring of 2017 with four tree species Picea abies, Pinus sylvestris, Alnus glutinosa and Betula pendula and three seedling types were used, bare roots, containerized and improved root system. The evaluation of survival and measure of annual increment was conducted at the end of the first growing season in the autumn of 2017. Results showed that overall the highest seedling survival rate provided soil prepared in mound (90\%), and seedlings with improved root system, though the lowest survival rate was observed for bare root seedlings. Containerized seedlings have a higher proportional increment if compared to bare root and improved root system seedlings, but differences are not significant yet $(\mathrm{p}>0.05)$. In conclusion, the survival rate of outplanted seedlings differs by chosen stocktype and soil preparation method used in forest regeneration and for various tree species impact of chosen stock type on survival rate differs.
\end{abstract}

Key words: soil preparation, stocktype, seedling establishment.

\section{Introduction}

Latvia is located in the boreo-nemoral zone; therefore, forests consist of coniferous and broadleave tree species (Hytterborn et al., 2005). All together forests cover approximately $52 \%$ of Latvia. There are three dominant tree species Scots pine (Pinus sylvestris), Norway spruce (Picea abies) and Silver Birch (Betula pendula Roth) that occupy 33.3\%, 18.2\%, 30.8\%respectively, but black alder (Alnus glutinosa) occupies 3.2\% of forests in Latvia (Valst meža dienests, 2018). The forest management has intensified in the last 20 years (Tērauds, Brūmelis, \& Nikodemus, 2011). That is one of the reasons why successful early stage of reforestation is crucial for cost-efficient and sustainable forest management. Reforestation with planting is common practice in forestry that developed in late 19th century and from that time planting methods have been developing. There are two main milestones that will determine the success of reforestation. The chosen soil preparation method and used stocktype (Sutton, 1993). In 1920's Latvian foresters concluded that in successful artificial reforestation soil preparation is one of key elements, that positively changes edaphic factors (Kundziņš, 1939). The aim of soil preparation in forestry is to achieve higher tree seedling establishment and promote their growth and improve $\mathrm{C}$ - fixation. Many studies show that mechanical soil preparation methods improve the quality of forest regeneration in boreal forests (Mjöfors et al., 2017). There are many soil preparation methods, but disc trenching is the most widely used one in boreal forests (Henneb et al., 2015) and in Latvia soil preparation in furrows by disc trenching is also the most popular method although also other methods are used with some advantages in certain conditions, for example, spot mounding has been used in Latvia state forests since 2013 (Lazdina, 2012).

Correctly prepared soil is important because right after planting seedlings are exposed to new environmental conditions that can be stressful for them and chosen method can reduce stress factors. For example, the root growth is essential for successful seedling establishment, because roots provide water for transpiration. Soil compaction, ion concentration, water content, soil temperature, root system size and distribution impact functionality of roots and determines the survival of the seedling (Grossnickle, 2005). Seedling type with larger root volume can increase survival rate in certain environmental conditions (Haase \& Rose, 1993). Soil preparation also mixes organic humus layer with mineral soil and exposure of mineral soil reduces seedling damage by pine weevil (Nordlander et al., 2011). Created tilts, mounds and furrows positively stabilize soil moisture conditions by reducing free water content in overwet sites and raise moisture content at dry conditions (Sutinen et al., 2006). Soil preparation methods can change the $\mathrm{C}$ sequestration and $\mathrm{N}$ composition in soil (Piirainen, Finér, \& Starr, 2015), and the study represents that soil preparation in furrows and ridges promotes $\mathrm{Ca}^{2+}, \mathrm{Mg}^{2+}, \mathrm{Al}^{3+}$. $\mathrm{Fe}^{3+}, \mathrm{H}+$ leaching from the upper $\mathrm{B}$ horizon compared to the untraded soil (Piirainen et al., 2009) and reduces the concentration 
of $\mathrm{F}^{-}, \mathrm{Br}^{-}$. No ${ }^{2-}$ ions (Ring, Högbom, \& Jansson, 2013). Scientists have determined the pattern: if the disturbance is higher than ion leaching is also higher and potassium leaching reaches the highest point right after the soil preparation (Piirainen et al., 2009). Soil preparation changes microtopography that causes favorable microclimatic conditions for decomposing organisms, because of changed environmental condition that are higher temperature, moisture, oxygen content, favourable organic and mineral soil mixture for microorganisms compared with untreated soil. All these factors together increase biological activity, including nitrogen releases happen faster in for example disc trenched soil than in unprepared soil (Lundmark-Thelin \& Johansson, 1997) and the lack of plant available nitrogen is one of the key factors that determines plant growth (Örlander, Nilsson, \& Hällgren, 1996). Mounding especially increases the soil temperature (Sutton, 1993), and increased soil temperature promotes chemical processes and root growth that stimulate nutrient and water uptake (Mellander, Bishop, \& Lundmark, 2004), in first years after planting mounding better reduces competition for water between ground vegetation and seedlings than disc trenching in the result of reducing mortality (Archibold, Action, \& Ripley, 2000), reduce risk of frost damage (Langvall, Nilsson, \& Örlander, 2001). Research carried out by Örlander, Nilsson, \& Hällgren (1996) showed that mounding does not increase nitrogen leaching in the first year after clearcut. Research done with Norway spruce and Scots pine seedlings planted on mounds showed a positive effect of this method in the increased survival rate and successful establishment on moist clear-cut forest sites (Mäkitalo, 1999; Hallsby \& Örlander, 2004), and this soil preparation method has a lower negative impact of the surrounding environment (Hallsby \& Örlander, 2004).

Although disc trenching is a more commonly used technique, an area of soil prepared in spot mounds increases in Latvia especially in Myrtilloso sphagnosa (Lazdina et al., 2015). Altogether the seedling establishment and their vitality represent environmental conditions like nutrient availability, water content, temperature in different kind of planting spots (Heiskanen, Saksa, \& Luoranen, 2013), but there could be one negative effect that scientists have observed that in some cases healthier coniferous seedlings are more browsed and intensity of browsing correlates with the color of the needles (Bergquist, Bergström, \& Zakharenka, 2003).

Besides the right soil preparation method also the right choice for stocktype is important. For example, in comparison between bare-root and containerized Scots pine seedlings, a significant higher survival rate at the end of the first vegetation season showed containerized seedlings (Kḷvinina, Gaitnieks, \& Menkis, 2013).

The aim of this study was to evaluate the impact of different soil preparation methods and used type of seedlings on tree survival and growth rate after the first growing season.

\section{Materials and Methods}

The study was conducted at six young stand sites on mineral soils, which were combined into three pairs depending on planting conditions and tree species and seedling type composition (Table 1). Four of these young stands are located in the north-west part of Latvia, in the county of Dundaga. One pair of sites is

Table 1

\section{Tree species and seedling type outplanted in three forest types}

\begin{tabular}{|l|c|c|c|}
\hline \multicolumn{1}{|c|}{ Species and seedlings } & Vacciniosa mel. & Myrtilloso-sphagnosa & Myrtillosa mel. \\
\hline Spruce, bare roots & - & $\times$ & $\times$ \\
\hline Spruce, containerized & - & $\times$ & $\times$ \\
\hline Spruce, improved root system & - & $\times$ & - \\
\hline Birch, bare roots & - & $\times$ & $\times$ \\
\hline Birch, containerized & - & $\times$ & $\times$ \\
\hline Birch, improved root system & - & $\times$ & $\times$ \\
\hline Black alder, bare roots & - & $\times$ & $\times$ \\
\hline Black alder, containerized & - & $\times$ & $\times$ \\
\hline Black alder, improved root system & - & $\times$ & $\times$ \\
\hline Pine, containerized & $\times$ & $\times$ & $\times$ \\
\hline Pine, bare roots & $\times$ & $\times$ & $\times$ \\
\hline
\end{tabular}

* ( $\times$ variant that was represented in the forest type, - variant that was not represented in the forest type). 
drained (Vacciniosa mel. forest type) with total area of 3 ha (not all planted area used in this study) located at $57.560735^{\circ} \mathrm{N}, 22.563554^{\circ} \mathrm{E}$ and $57.558883^{\circ} \mathrm{N}$, $22.564405^{\circ} \mathrm{E}$, whereas sites of the other pair are with natural water regime (Myrtilloso-sphagnosa) with a total area of 3 ha, located at $57.548045^{\circ} \mathrm{N}, 22.537190^{\circ} \mathrm{E}$ and $57.546587^{\circ} \mathrm{N}, 22.540432^{\circ} \mathrm{E}$. Last two young stands are located in the central part of Latvia, in the county of Ozolnieki. The soil in both sites are drained (Myrtillosa mel.) with the total area of 2.8 ha, located at $56.722162^{\circ} \mathrm{N}, 23.938307^{\circ} \mathrm{E}$ and $56.721674^{\circ} \mathrm{N}$, $23.941383^{\circ} \mathrm{E}$. Each study site was divided into three parts according to what soil preparation method was used and the same methods were applied in all study sites. One part of forest land was prepared with disc trenching, the second part with spot mounding method and the third part between both other methods was left unprepared. The soil preparation was conducted in the autumn of 2016 and all these study sites were reforested by planting in the spring of 2017.

Data collection was conducted from September to November 2017. Four study plots per seedling type were established for data collection at every young stand at mounds and furrows, whereas at unprepared soil every tree was observed. Sampling plots at mounds were randomly established with an area of $25 \mathrm{~m}^{2}(\mathrm{r}=2.82 \mathrm{~m})$, and in furrows, the same size sapling plots were established (10 m long and $2.5 \mathrm{~m}$ wide). In furrows, sampling plots were distributed in straight lines and the first sapling plot started $10 \mathrm{~m}$ from the beginning of the furrow while the distance between plots was $10 \mathrm{~m}$. The total amount of sample plots at mounds are 146 and 298 in furrows. Total height and annual increment were measured for every living tree in a sampling plot and all died back trees were counted.

The survival rate for each seedling type in each forest type was calculated by dividing count of died back trees with a count of planted trees in sampling plots. The seedling proportional increment was calculated by dividing annual increment with total height. Values were expressed as a percentage and for both parameters standard error (SE) was calculated. Mean values of a seedling proportional increment within one tree species were analyzed by two-way analysis of variance (ANOVA) and Tukey's test. Tests were done with a 95\% confidence level and calculations were done by $\mathrm{R}$ program for Statistical Computing, Core Team (2017) version 3.4.1.

\section{Results and Discussion}

After the first growing season the highest overall seedling survival rate was determined in soil prepared in spot mounds $(90.0 \pm 1.03 \%)$, in soil prepared by disc trenching survived $86.8 \pm 0.83 \%$, but in unprepared soil $88.7 \pm 0.84 \%$ of all outplanted seedlings and these results confirm previous studies that planting on mounds increase planted tree survival due to favorable nutrient availability and higher soil temperature (Sutton, 1993; Mäkitalo, 1999; Hallsby \& Örlander, 2004).

\section{Seedling survival rate $(\%)$ in three forest types depending on soil preparation method}

\begin{tabular}{|l|c|c|c|c|c|c|}
\hline \multirow{2}{*}{\multicolumn{1}{|c}{ Species and seedlings }} & \multicolumn{2}{|c|}{ Myrtilloso-sphagnosa mean \pm SE } & \multicolumn{3}{c|}{ Myrtillosa mel. mean \pm SE } \\
\cline { 2 - 7 } & $\mathrm{Dt}$ & $\mathrm{M}$ & $\mathrm{U}$ & $\mathrm{Dt}$ & $\mathrm{M}$ & $\mathrm{U}$ \\
\hline Spruce, bare roots & $92.5 \pm 2.94$ & $94.6 \pm 3.71$ & $91.5 \pm 3.08$ & $93.5 \pm 2.22$ & $94.8 \pm 3.53$ & 100 \\
\hline Spruce, containerized & $92.7 \pm 3.12$ & $97.5 \pm 2.48$ & $94.5 \pm 2.39$ & $96.1 \pm 1.90$ & $93.7 \pm 3.52$ & $96.6 \pm 3.27$ \\
\hline $\begin{array}{l}\text { Spruce, improved root } \\
\text { system }\end{array}$ & $96.2 \pm 2.17$ & 100 & $96.0 \pm 1.96$ & $99.0 \pm 0.85$ & $95.7 \pm 2.94$ & 100 \\
\hline Birch, bare roots & $88.6 \pm 5.38$ & $95.2 \pm 0.28$ & $89.6 \pm 4.41$ & $\times$ & $\times$ & $80.7 \pm 7.72$ \\
\hline Birch, containerized & $94.4 \pm 2.73$ & $97.4 \pm 2.53$ & $92.3 \pm 0.84$ & $83.6 \pm 3.52$ & $81.8 \pm 6.71$ & $95.2 \pm 2.34$ \\
\hline Birch, improved root system & $97.2 \pm 1.82$ & 100 & $96.7 \pm 1.83$ & $82.4 \pm 3.67$ & $91.2 \pm 4.86$ & $83.3 \pm 8.78$ \\
\hline Black alder, bare roots & $\times$ & $\times$ & $\times$ & $75.8 \pm 7.42$ & $84.2 \pm 8.36$ & $87.5 \pm 11.7$ \\
\hline Black alder, containerized & $94.3 \pm 2.77$ & 100 & $94.7 \pm 2.56$ & $93.8 \pm 4.28$ & $94.7 \pm 3.62$ & $92.0 \pm 5.42$ \\
\hline $\begin{array}{l}\text { Black alder, improved root } \\
\text { system }\end{array}$ & 100 & 100 & 100 & $88.6 \pm 5.34$ & $\times$ & $\times$ \\
\hline Pine, containerized & $98.6 \pm 1.31$ & 100 & $93.6 \pm 2.77$ & $84.1 \pm 4.03$ & $93.8 \pm 3.42$ & $95.5 \pm 2.52$ \\
\hline Pine, bare roots & $82 \pm 3.66$ & $93.7 \pm 4.28$ & $71.1 \pm 6.28$ & $79.1 \pm 4.5$ & $78.5 \pm 6.33$ & $98.2 \pm 1.12$ \\
\hline
\end{tabular}

* (Dt - disc trenching, $\mathrm{M}$ - mounding, $\mathrm{U}$ - unprepared soil, $\times$ - variant that was not represented in the forest type). 


\section{The seedling proportional mean increment in three forest types depending on soil preparation method \%}

Table 3

\begin{tabular}{|l|c|c|c|c|c|c|}
\hline \multirow{2}{*}{ Species and seedlings } & \multicolumn{3}{|c|}{ Myrtilloso-sphagnosa mean \pm SE } & \multicolumn{3}{c|}{ Myrtillosa mel. mean \pm SE } \\
\cline { 2 - 7 } & $\mathrm{Dt}$ & $\mathrm{M}$ & $\mathrm{U}$ & $\mathrm{Dt}$ & $\mathrm{M}$ & $\mathrm{U}$ \\
\hline Spruce, bare roots & $12.1 \pm 0.73^{\mathrm{a}}$ & $12.1 \pm 0.74^{\mathrm{ab}}$ & $17.16 \pm 1.1^{\mathrm{bc}}$ & $17.9 \pm 0.85^{\mathrm{c}}$ & $16.5 \pm 1.25^{\mathrm{ac}}$ & $19.5 \pm 1.87^{\mathrm{cf}}$ \\
\hline Spruce, containerized & $23.9 \pm 0.9^{\mathrm{ef}}$ & $23.1 \pm 1.48^{\mathrm{def}}$ & $23.4 \pm 0.65^{\mathrm{ef}}$ & $25.9 \pm 1.23^{\mathrm{e}}$ & $24.7 \pm 1.30^{\mathrm{ef}}$ & $19.5 \pm 1.35^{\mathrm{bce}}$ \\
\hline $\begin{array}{l}\text { Spruce, improved root } \\
\text { system }\end{array}$ & $23.6 \pm 0.87^{\mathrm{ef}}$ & $20.5 \pm 0.87^{\mathrm{cf}}$ & $18.8 \pm 0.70^{\mathrm{cd}}$ & $15.7 \pm 0.63^{\mathrm{ac}}$ & $17.6 \pm 0.86^{\mathrm{bcd}}$ & $15.2 \pm 0.80^{\mathrm{ac}}$ \\
\hline Birch, bare roots & $20.1 \pm 2.01^{\mathrm{ab}}$ & $25.2 \pm 1.04^{\mathrm{ac}}$ & $20.0 \pm 1.00^{\mathrm{a}}$ & $\times$ & $\times$ & $24.7 \pm 2.91^{\mathrm{ac}}$ \\
\hline Birch, containerized & $25.5 \pm 2.16^{\mathrm{ac}}$ & $30.1 \pm 1.59^{\mathrm{cd}}$ & $27.5 \pm 1.31^{\mathrm{bc}}$ & $34.7 \pm 1.33^{\mathrm{de}}$ & $39.7 \pm 2.58^{\mathrm{e}}$ & $22.6 \pm 1.81^{\mathrm{ac}}$ \\
\hline $\begin{array}{l}\text { Birch, improved root } \\
\text { system }\end{array}$ & $26.0 \pm 0.87^{\mathrm{ac}}$ & $29.5 \pm 1.07^{\mathrm{bcd}}$ & $25.9 \pm 0.75^{\mathrm{ac}}$ & $30.1 \pm 1.49^{\mathrm{cd}}$ & $25.3 \pm 1.93^{\mathrm{ac}}$ & $32.8 \pm 2.05^{\mathrm{cb}}$ \\
\hline Black alder, bare roots & $\times$ & $\times$ & $\times$ & $45.3 \pm 2.62^{\mathrm{f}}$ & $65.5 \pm 2.99^{\mathrm{g}}$ & $44.5 \pm 11.95^{\mathrm{f}}$ \\
\hline $\begin{array}{l}\text { Black alder, } \\
\text { containerized }\end{array}$ & $19.6 \pm 0.95^{\mathrm{ab}}$ & $20.6 \pm 1.24^{\mathrm{ac}}$ & $18.8 \pm 0.67^{\mathrm{a}}$ & $27.0 \pm 1.39^{\mathrm{ce}}$ & $30.9 \pm 3.93^{\mathrm{e}}$ & $40.7 \pm 1.07^{\mathrm{f}}$ \\
\hline $\begin{array}{l}\text { Black alder, improved } \\
\text { root system }\end{array}$ & $27.0 \pm 1.55^{\mathrm{de}}$ & $29.3 \pm 1.71^{\mathrm{de}}$ & $23.8 \pm 0.89^{\mathrm{bcd}}$ & $25.6 \pm 1.76^{\mathrm{bce}}$ & $\times$ & $\times$ \\
\hline Pine, containerized & $50.8 \pm 1.37^{\mathrm{f}}$ & $45.6 \pm 1.64^{\mathrm{cf}}$ & $38.7 \pm 1.31^{\mathrm{c}}$ & $43.2 \pm 1.71^{\text {cde }}$ & $46.8 \pm 1.38^{\mathrm{df}}$ & $48.5 \pm 1.69^{\mathrm{ef}}$ \\
\hline Pine bare roots & $31.2 \pm 1.14^{\mathrm{ab}}$ & $39.2 \pm 1.75^{\mathrm{bcd}}$ & $29.3 \pm 1.78^{\mathrm{a}}$ & $40.5 \pm 1.57^{\mathrm{cd}}$ & $45.4 \pm 2.56^{\mathrm{cf}}$ & $44.8 \pm 1.78^{\mathrm{cf}}$ \\
\hline
\end{tabular}

(Dt - disc trenching, $\mathrm{M}$ - mounding, $\mathrm{U}$ - unprepared soil, the different superscript letters represent a significant difference between means within one tree species, by ANOVA and Tukey's pairwise comparison test $\mathrm{p}<0.5$. $\times-$ variant that was not represented in the forest type)

The lowest survival rate was determined for pine bare root seedlings in Vaccinosa mel. forest type, respectively $19.6 \pm 5.55 \%$ in soil prepared in mounds and only $12.97 \% \pm 3.32 \%$ in disc trenched soil and in unprepared soil survived $13.63 \% \pm 3.72 \%$ of planted trees, although survival rate of containerized pine seedlings was significantly higher in this forest type, respectively over $95 \%$ in both soil preparation methods and in unprepared soil and also in two other forest types scots pine bare root seedlings had a lower survival rate than containerized seedlings (Table 2). Other authors have obtained similar results (Kḷaviņa, Gaitnieks, \& Menkis, 2013). Disregarding pine containerized seedlings, black alder bare root seedlings in disc trenched soil had the lowest survival rate. Right after outplanting seedlings must adapt to new environmental conditions and overcome stress factors and in volume larger seedling roots can increase survival rate because of providing a sufficient amount of water for transpiration (Haase \& Rose, 1999; Grossnickle, 2005). Our study confirmed it as overall highest first year survival was determined for Norway spruce and black alder improved root system seedlings (Table 2 ).

One of advantages of soil preparation in mounds is reduced competitive vegetation compared to disc trenching and unthreaded soil that not only improves survival (Archibold, Action, \& Ripley, 2000) but also reduces the damage rate caused by agrotechnical care because the planting spot on mounds is easier to find. Overall, $8.4 \%$ and $5.2 \%$ of seedlings in furrows and untraded soil were damaged compared to $1.4 \%$ of damaged seedlings planted on mounds during agrotechnical care.

After the first growing season, the highest proportional increment was calculated for black alder bare roots and pine seedlings (Table 3), except in Vacciniosa mel. forest type, where pine bare roots seedlings had a lower proportional increment compared to containerized seedlings, respectively $19.4 \pm 2.32 \%$ against $46.5 \pm 0.78 \%$ in soil prepared by disc trenching, $22.2 \pm 2.45 \%$ against $48.4 \pm 1.64 \%$ in mounds, but in unprepared soil the difference was lower: $32.9 \pm 3.78 \%$ against $52.3 \pm 0.78$. Other research studies show the same trend that containerized scots pine seedlings have a higher growth rate compared to bare root seedlings (Kḷavina, Gaitnieks, \& Menkis, 2013). The lowest annual increment was observed and calculated for spruce bare roots and improved root system seedlings, and altogether there is a slight trend that bare root and improved root system seedlings have a lower proportional increment compared to containerized seedlings in the first year after outplanting (Table 3). Other researchers report similar results that in the first years after outplanting containerized seedlings have greater growth rate (Renou-Wilson, Keane, \& Farrell, 2008). 
One of the aims of soil preparation is to enhance a tree growing rate, by providing appropriate environmental conditions (Löf et al., 2012) and evaluating the impact of soil preparation method on seedling growth rate the birch and black alder trees planted on mounds had a higher growth rate up to 65.5 $\pm 2.99 \%$ annual increment of total height for black alder bare root seedlings. In the Myrtilloso-sphagnosa forest type seedlings planted in unprepared soil had a lower growth rate than those planted on mounds and in furrows, except spruce containerized trees, who produced a similar growth rate in all soil preparation variants (Table 3).

\section{Conclusions}

The survival rate of outplanted seedlings differ by a chosen stocktype and soil preparation method from lower than 20\% survived scots pine bare root seedlings and reaching up to $100 \%$ survival rate of spruce, black alder seedlings planted on mounds and altogether soil preparation tend to increase a planted tree survival.

After seedling outplanting from a nursery in the forest land containerized seedling have a higher mean proportional increment $(35.9 \pm 0.42 \%)$ compared to other stocktype (26.6 $\pm 0.61 \%$ for bare roots and 23.1 $\pm 0.31 \%$ improved root system $(\mathrm{p}<0.05))$.

Soil preparation method also impacts the damage rate caused by agrotechnical care from $1.4 \%$ on mounds to $8.4 \%$ damaged trees in furrows made by disc trenching.

\section{Acknowledgments}

The study was carried out in JSC 'Latvian State Forests'researchprogramNo.5-5.5_000p_101_16_22.

\section{References}

1. Archibold, O.W., Acton, C., \& Ripley, E.A. (2000). Effect of site preparation on soil properties and vegetation cover, and the growth and survival of white spruce (Picea glauca) seedlings, in Saskatchewan. Forest Ecology and Management, 131(1-3), 127-141.

2. Bergquist, J., Bergström, R., \& Zakharenka, A. (2003). Responses of young Norway spruce (Picea abies) to winter browsing by roe deer (Capreolus capreolus): Effects on height growth and stem morphology. Scandinavian Journal of Forest Research, 18(4), 368-376. DOI: 10.1080/0282758031005431.

3. Grossnickle, S.C. (2005). Importance of root growth in overcoming planting stress. New Forests, 30(2-3), 273-294. DOI: 10.1007/s11056-004-8303-2.

4. Haase, D.L., \& Rose, R. (1993). Soil moisture stress induces transplant shock in stored and unstored 2+ 0 Douglas-fir seedlings of varying root volumes. Forest Science, 39(2), 275-294.

5. Hallsby, G., \& Örlander, G. (2004). A comparison of mounding and inverting to establish Norway spruce on podzolic soils in Sweden. Forestry, 77(2), 107-117. DOI: 10.1093/forestry/77.2.107.

6. Heiskanen, J., Saksa, T., \& Luoranen, J. (2013). Soil preparation method affects outplanting success of Norway spruce container seedlings on till soils susceptible to frost heave. Silva Fennica, 47(1), 345-351. DOI: $10.14214 /$ sf.893.

7. Henneb, M., Valeria, O., Fenton, N.J., Thiffault, N., \& Bergeron, Y. (2015). Mechanical site preparation: Key to microsite creation success on Clay Belt paludified sites. The Forestry Chronicle, 91(2), 187-196. DOI: $10.5558 /$ tfc2015-030.

8. Hytteborn, H., Maslov, A.A., Nazimova, D.I., \& Rysin, L.P. (2005). Boreal forests of Eurasia. In F.A. Anderson (Eds.), Coniferous forests, ecosystems of the world. Sixth ed. (pp. 23-99). Amsterdam, Netherlands: Elsevier.

9. Klavina, D., Gaitnieks, T., \& Menkis, A. (2013). Survival, growth and ectomycorrhizal community development of container-and bare-root grown Pinus sylvestris and Picea abies seedlings outplanted on a forest clear-cut. Balt For, 19(1), 39-49.

10. Kundziņšs, A. (1939). Daži dati un vērojumi priežu sēšanas izmēǵinājumos (Some data and observations in pine seeding trials). Mežsaimniecības rakstu krājums. 17, pp. 24-39. (in Latvian).

11. Langvall, O., Nilsson, U., \& Örlander, G. (2001). Frost damage to planted Norway spruce seedlingsinfluence of site preparation and seedling type. Forest Ecology and Management, 141(3), 223-235. DOI: 10.1016/S0378-1127(00)00331-5.

12. Lazdina, D. (2012). The choice of Soil preparation method in wetlands, peatlands theoretical ground, labor capacity and cost-benefit study. Salaspils: Latvian State Forest Research Institute 'Silava'

13. Lazdina, D., Lazdins, A., Bardulis, A., Liepins, J., Prindulis, U., Zimelis, A., \& Jansons, A. (2015). Mounding as method of reforestation of wet and 'problematic' forests on organic soils in Latvia. In Forest engineering: Making a positive contribution $48^{\text {th }}$ Symposiom on Forest Mechanization, 4-8 October 2015 (pp. 91-93). Linz, Austria: Institute of Forest Engineering, University of Natural Resources and Life Sciences. 
14. Löf, M., Dey, D.C., Navarro, R.M., \& Jacobs, D.F. (2012). Mechanical site preparation for forest restoration. New Forests, 43(5-6), 825-848. DOI: 10.1007/s11056-012-9332.

15. Lundmark-Thelin, A., \& Johansson, M.B. (1997). Influence of mechanical site preparation on decomposition and nutrient dynamics of Norway spruce (Picea abies (L.) Karst.) needle litter and slash needles. Forest Ecology and Management, 96(1-2), 101-110. DOI: 10.1016/S0378-1127(97)00040-6.

16. Mäkitalo, K. (1999). Effect of site preparation and reforestation method on survival and height growth of Scots pine. Scandinavian Journal of Forest Research, 14(6), 512-525. DOI: 10.1080/02827589908540816.

17. Mellander, P.E., Bishop, K., \& Lundmark, T. (2004). The influence of soil temperature on transpiration: a plot scale manipulation in a young Scots pine stand. Forest Ecology and Management, 195(1-2), 15-28. DOI: $10.1016 /$ j.foreco.2004.02.051.

18. Mjöfors, K., Strömgren, M., Nohrstedt, H.Ö., Johansson, M.B., \& Gärdenäs, A.I. (2017). Indications that site preparation increases forest ecosystem carbon stocks in the long term. Scandinavian Journal of Forest Research, 32(8), 717-725. DOI: 10.1080/02827581.2017.1293152.

19. Nordlander, G., Hellqvist, C., Johansson, K., \& Nordenhem, H. (2011). Regeneration of European boreal forests: effectiveness of measures against seedling mortality caused by the pine weevil Hylobius abietis. Forest Ecology and Management, 262(12), 2354-2363. DOI: 10.1016/j.foreco.2011.08.033.

20. Örlander, G., Nilsson, U., \& Hällgren, J.E. (1996). Competition for water and nutrients between ground vegetation and planted Picea abies. New Zealand Journal of Forest Science, 26(1-2), 99-117.

21. Piirainen, S., Finér, L., \& Starr, M. (2015). Changes in forest floor and mineral soil carbon and nitrogen stocks in a boreal forest after clear-cutting and mechanical site preparation. European Journal of Soil Science, 66(4), 735-743. DOI: 10.1111/ejss.12264.

22. Piirainen, S., Finér, L., Mannerkoski, H., \& Starr, M. (2009). Leaching of cations and sulphate after mechanical site preparation at a boreal forest clear-cut area. Geoderma, 149(3-4), 386-392. DOI: 10.1016/j.geoderma.2009.01.003.

23. Renou-Wilson, F., Keane, M., \& Farrell, E.P. (2008). Effect of planting stocktype and cultivation treatment on the establishment of Norway spruce on cutaway peatlands. New Forests, 36(3), 307-330. DOI: 10.1007/ s11056-008-9102-y.

24. Ring, E., Högbom, L., \& Jansson, G. (2013). Effects of previous nitrogen fertilization on soil-solution chemistry after final felling and soil scarification at two nitrogen-limited forest sites. Canadian Journal of Forest Research, 43(4), 396-404. DOI: 10.1139/cjfr-2012-0380.

25. Valsts meža dienests (2018, August). Meža statistika (Forest statistics). Retrieved August 28, 2018, from: http://www.vmd.gov.lv/valsts-meza-dienests/statiskas-lapas/publikacijas-un-statistika/meza-statistikascd?nid=1809\#jump. (in Latvian).

26. Sutinen, R., Pänttäjä, M., Teirilä, A., \& Sutinen, M.L. (2006). Effect of mechanical site preparation on soil quality in former Norway spruce sites. Geoderma, 136(1-2), 411-422. DOI: 10.1016/j. geoderma.2006.04.018.

27. Sutton, R.F. (1993). Mounding site preparation: a review of European and North American experience. New Forests, 7(2), 151-192. DOI: 10.1007/BF00034198.

28. Tērauds, A., Brūmelis, G., \& Nikodemus, O. (2011). Seventy-year changes in tree species composition and tree ages in state-owned forests in Latvia. Scandinavian Journal of Forest Research, 26(5), 446-456. DOI: 10.1080/02827581.2011.586647. 